\title{
VIT D DEFICIENCY; DIVIDE TRIALS (DILEMA AT CIVIL OPD HYDERABAD) dr_santosh72@yahoo.com
}

1. Assistant Professor Med LUMHS, Jamshoro, Hyderabad

2. Assistant Professor Cardiology LUMHS, Hyderabad

3. Nephrologist

LUMHS, Hyderabad

4. MO Matiari, Hyderbad.

Correspondence Address: Dr. Santosh Kumar

Ass: Professor Med LUMHS Jamshoro, Hyderabad.

dr_santosh72@yahoo.com

Article received on: 10/03/2016 Accepted for publication: $21 / 07 / 2016$

Received after proof reading: 10/09/2016

\section{Dr. Santosh Kumar', Dr. Gaffar Memon², Dr. Bagwan Das ${ }^{3}$, Dr. Pushpa Mohan ${ }^{4}$}

\begin{abstract}
Objectives: To determine the outcome of vitamin deficiency in local population of (Hyderabad), come with complaints of vague symptoms of body ache, bony pain with no co morbidity. Study design: cross-sectional study. Place and duration of study: Outpatient Department of Liquat University Medical Science, Hyderabad. Period: 6-2-2013 to 6-2-2015. Methodology: This is observational cross sectional study conducted at out patient's department (LUMHS) city Hyderabad from 6-2-13 to 6-2-2015. Preliminary data was collected with the help of self-administered questionnaires which include patient's history and examination and blood sample is taken for assessing level of dehydrocholecalciferol with serum calcium and routine test. Data entered in spss 20 version, analytical software were applied for results in this study. Result: This study is conducted in 300 pts, among these $60 \%$ female and $36.7 \%$ male and $3.3 \%$ missing. Patients selected through (OPD) with consent and preformed proforma. Vitamin $d$ deficiency found nearly $96 \%$ in all the patient from young age to old age $4 \%$ were missing, less than 10 level found in $24.7 \%$ (severe deficiency), $10-20$ level seen $54.7 \%$ (moderate deficiency) and $20-30$ found in $14.7 \%$ (mild deficiency). Conclusion: my results shows that (vitamin D-deficiency) is big dilemma in our community, give rise mild, moderate and severe decreased level which leads complication which causing rickets in children and osteomalcia in adults, increase mortality and morbidity in local population.
\end{abstract}

Key words: Incidence, Vitamin D level, OPD, age, Hyderabad.

Article Citation: Kumar S, Memon G, Das B, Mohan P. Vit D deficiency; divide trials (Dilema at Civil OPD Hyderabad). Professional Med J 2016;23(9):1064-1067. DOI: 10.17957/TPMJ/16.3221

\section{INTRODUCTION}

We live in the era of world where illiteracy rate are higher than other part of the region. People doesn't know about the basic right of life, like sanitation of water, education, health facility, employment or self-insurance etc. So many health problem is running in communities which can be prevented by proper awareness and education out of them vit $d$ is treatable issue could be solved. (Vitamin D) is important hormone formed in skin from ultra violet rays through cholecalciferol convert in liver to 24 de - hydrocholcalciferol to change active form 1-25 dehydrocholecalciferol in kidney then it regulate calcium absorption from gastrointestinal system. Like in advanced countries like America, Australia, Canada, Japan but in under developed like Pakistan is still a major health problem. ${ }^{1,2}$ There are many multifactorial cause for vitamin deficiency with systemic illness but in normal healthy there is only lack of proper exposure to sun light. Evidence suggests that vit $d$ in sufficiency produce major health problem and bony deformities and abnormalities in muscle, and rarely do it may leads abnormality in brain with weakness neuropathy and fits and from hair loss to dermatological manifestation. ${ }^{3-4}$

Sunlight exposure promotes vitamin D synthesis due to many factors it causing deficiency in hot area of world especially South Asia, but proper knowledge and awareness we would overcome the issue. ${ }^{22-25}$ We have been measuring 25-hydroxyvitamin D levels in unselected outpatients in an affluent sunny hot area of (Hyderabad). Vit $d$ is the most common cause of osteomalcia and its incidence increase throughout the world as results of diminished exposure to sunlight caused by urbanization automobile and public transportation and modest clothing ., 5,20-21 


\section{MATERIAL AND METHODS}

This is prospective observational study is conducted in civil opd Hyderabad from 6-2-13 to $30-12-15$.consent and prerequisite proforma filled by the patients after proper examination and lab reports with proper guideline and results compare with national and international articles. All data and variable entered in spss 20 versions and analytical software applied for results.

\section{RESULTS}

This study is conducted in 300 patients, $60 \%$ were females and $36.7 \%$ male and $3.3 \%$ missing (Table-I). The serum calcium level found low $47 \%$ of pt and normal $49 \%$ of pt and $4 \%$ were missing. (Table-l) and bar graph shows vitamin d deficiency found nearly $96 \%$ in all the pt from young age to old age, $4 \%$ were missing, less than 10 level found in $24.7 \%$ (severe deficiency), 10-20 level seen $54.7 \%$ (moderate deficiency) and $20-30$ found in $14.7 \%$ (mild deficiency).

\begin{tabular}{|r|c|c|c|}
\hline \multicolumn{2}{|c|}{ Character } & N & $\%$ \\
\hline \multirow{3}{*}{ Age } & $<10$ years & 74 & 24.7 \\
\cline { 2 - 4 } & $\mathbf{1 0 - 2 0}$ years & 164 & 54.7 \\
\cline { 2 - 4 } & $>\mathbf{2 0}$ years & 50 & 14.7 \\
\hline \multirow{2}{*}{ Sex } & Female & 180 & 120 \\
\cline { 2 - 4 } & Male & 110 & 36.7 \\
\hline
\end{tabular}

Table-I. Characteristics of age and gender percentage $(n=292)$

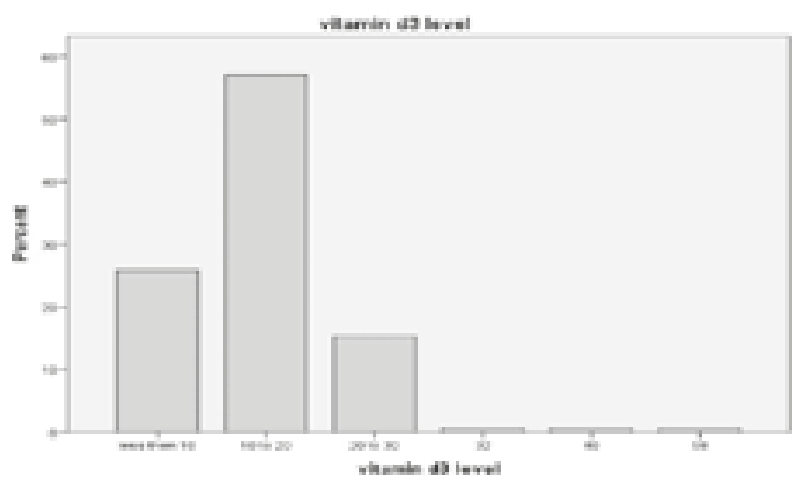

Figure-1. Frequency of vitamin D3 levels.

\section{DISCUSSION}

This is cross sectional study conducted in Outpatient Department Liaquat Medical College Jamshoro, Hyderabad because worldwide different study documented that vitamin $d$ deficiency is emerging a major health problem. There are different etiology of vitamin d deficiency like un exposed to ultraviolet rays, vegetarian, kidney disease etc but my study demonstrate that vitamin deficiency multifactorial especially un exposed body to sun is very important cause in our society. Many published articles, 5-15-16-17-18-19 Evidence suggests that vit $d$ is more important for health and bone physiology. ${ }^{22-25}$ My observational study is recommend that vit $D$ deficiency is more high in our part of region as compared to other study of world. Significant (vit D deficiency) or less than $20 \mathrm{ng} /$ liter was found in $24 \%$ of postmenopausal women from 25 countries. The incidence varied $<1 \%$ in south Asia $29 \%$ in United States and $36 \%$ in Italy. Patients in whom severe vit d deficiency found leads (osteomalcia) in adults and (rickets) in children level less than $10 \mathrm{ng}$ per liter. The prevalence of severe vitamin deficiency is $3.5 \%$ in United States and $12.5 \%$ in Italy. ${ }^{25}$ Sunlight exposures promotes vitamin D synthesis due to many factors it causing deficiency in hot area of world especially South Asia, but proper knowledge and awareness we would overcome the issue..$^{22-25}$

\section{CONCLUSION}

My conclusion in this study that vitamin $D$ from mild, moderate and severe deficiency at local opd of lumhs Hyderabad, which causing major health hazards in adults and children like rickets and osteomalcia. So need urgent measure like public health awareness .media compain and seminar, round table discussion work shop to prevent further mortality and morbidity from vitamin deficiency in our local population of (Hyderabad). Copyright@ 21 July, 2016.

\section{REFERENCES}

1. Soliman AT, De Sanctis V, Elalaily R, Bedair S, Kassem I. Vitamin $D$ deficiency in adolescents. Indian $\mathrm{J}$ Endocrinal Metab. 2014 Nov; 18(Suppl 1):S9-S16.

2. Kim JH, Chang JH, Kim DY, Kang JW. Association between self-reported sleep duration and serum vitamin D level in elderly Korean adults. J Am Geriatric Soc. 2014 Dec; 62(12):2327-32.

3. Cheri CL, Raman P, Yin ZX, Shi XM, Zeng Y, Matchar DB. Vitamin $D$ levels and cognition in elderly adults in China. J Am Geriatric Soc. 2014 Nov; 62(11):2125-9. 
4. Angurana SK, Angurana RS, Mahajan G, Kumar N, Mahajan V. Prevalence of vitamin D deficiency in apparently healthy children in north India. J Pediatric EndocrinolMetab. 2014 Nov; 27(11-12):1151-6.

5. Choi JA, Han K, Park YM, La TY. Low serum 25-hydroxyvitamin $D$ is associated with myopia in Korean adolescents. Invest Ophthalmic Vis Sci. 2014 Apr 3; 55(4):2041-7.

6. Nimitphong $H$, Holick MF. Vitamin D status and sun exposure in Southeast Asia. Dermatoendocrinol. 2013 Jan $1 ; 5(1): 34-7$.

7. ArdeshirLarijani F, KalantarMotamedi SM, Keshtkar AA, Khashayar P, Koleini Z, Rahim F, Larijani B. The relation between serum vitamin $D$ levels and blood pressure: a population-based study. Acta Med Iran. 2014; 52(4):290-7.

8. Song HR, Kweon SS, Choi JS, Rhee JA, Lee YH, Nam HS, Jeong SK, Park KS, Ryu SY, Choi SW, Shin MH. High prevalence of vitamin $D$ deficiency in adults aged $\mathbf{5 0}$ years and older in Gwangju, Korea: the Dong-gu Study. J Korean Med Sci. 2014 Jan; 29(1):149-52.

9. Cinar N, Harmanci A, Yildiz BO, Bayraktar M. Vitamin D status and seasonal changes in plasma concentrations of 25-hydroxyvitamin $D$ in office workers in Ankara, Turkey. Eur J Intern Med. 2014 Feb; 25(2):197-201.

10. Khan $A H$, Nauruan $G$, lqbal $R$, Dar FJ. Assessing the effect of dietary calcium intake and 25 OHD status on bone turnover in women in Pakistan. Arch Osteoporos. 2013; 8(1-2):151.

11. Schodin BA. Vitamin D testing: the controversy continues. MLO Med Lab Obs. 2014 Jun; 46(6):16, 18.

12. Shuler FD, Schlierf T, Wingate $M$. Preventing falls with vitamin D. W V Med J. 2014 May-Jun; 110(3):10-2.

13. Ritterhouse LL, Lu R, Shah HB, Robertson JM, Fife DA, Maecker HT, Du H, Fathman CG, Chakravarty EF, Scofield RH, Kamen DL, Guthridge JM, James JA. Vitamin d deficiency in a multiethnic healthy control cohort and altered immune response in vitamin D deficient European-American healthy controls. PLoS One. 2014 Apr 11;9(4):

14. Iftikhar R, Kamran SM, Qadir A, Haider E, Bin Usman H. Vitamin $D$ deficiency in patients with tuberculosis. $J$ Coll Physicians Surg Pak. 2013 Nov; 23(10):780-3.

15. Iqbal R, Jafri L, Haroon A, Habib Khan A. Illuminating the dark side--vitamin D status in different localities of Karachi. J Coll Physicians Surg Pak. 2013 Aug; 23(8):604-6.

16. Baig JA, Sheikh SA, Islam I, Kumar M. Vitamin D status among vegetarians and non-vegetarians. J Ayub Med Coll Abbott bad. 2013 Jan-Jun; 25(1-2):152-5.

17. Humayun $Q$, Iqbal $R$, Azam I, Khan $A H$, Siddiqui $A R$, Baig-Ansari N. Development and validation of sunlight exposure measurement questionnaire (SEM-Q) for use in adult population residing in Pakistan. BMC Public Health. 2012 Jun 8; 12:421.

18. FernándezMartínezMdel M, Gómez Llorente JL, Martín González M, Momblan de Cabo J, Bonillo Perales A. Tetany secondary to deficiency rickets. Nutr Hosp. 2012 Mar-Apr; 27(2):656-8.

19. Husain N, Khanani R, Hussain-Kanani F, Shah T, Arif $S$, Pal L. High prevalence of vitamin D deficiency in Pakistani mothers and their newborns. Int J Gynaecol Obstet. 2011 Mar; 112(3):229-33.

20. Mansoor S, Habib A, Ghani F, Fatmi Z, Badruddin S, Mansoor S, Siddiqui I, Jabbar A. Prevalence and significance of vitamin $D$ deficiency and insufficiency among apparently healthy adults. Clin Biochem. 2010 Dec; 43(18):1431-5.

21. Zuberi LM, Habib A, Haque N, Jabbar A. Vitamin D Deficiency in ambulatory patients. J Pak Med Assoc. 2008 Sep; 58(9):482-4.

22. Kift R, Berry JL, Vail A, Durkin MT, Rhodes LE, Webb $A R$. Lifestyle factors including less cutaneous sun exposure contribute to starkly lower vitamin D levels in U.K. South Asians compared with the white population. Br J Dermatol. 2013 Dec; 169(6):1272-8.

23. Husain N, Khanani R, Hussain-Kanani F, Shah T, Arif $S$, Pal L. High prevalence of vitamin D deficiency in Pakistani mothers and their newborns. Int J Gynaecol Obstet. 2011 Mar; 112(3):229-33.

24. Lowe NM, Ellahi B, Bano Q, Bangash SA, Mitra SR, Zaman $M$. Dietary calcium intake, vitamin D status, and bone health in postmenopausal women in rural Pakistan. J Health PopulNutr. 2011 Oct; 29(5):465-70.

25. Song HR, Kweon SS, Choi JS, Rhee JA, Lee YH, Nam HS, Jeong SK, Park KS, Ryu SY, Choi SW, Shin MH. High prevalence of vitamin $D$ deficiency in adults aged $\mathbf{5 0}$ years and older in Gwangju, Korea: the Dong-gu Study. J Korean Med Sci. 2014 Jan; 29(1):149-52. 


\section{PREVIOUS RELATED STUDY}

Ahmed Bilal, Muhammad Owais Fazal, Fraz Saeed Qureshi, Muqqadas Shaheen, Muhammad Irfan Iqbal, Sadia Khan, Abdullah Bin Saeed. SERUM VITAMIN D DEFICIENCY, A NEW EPIDEMIC (Original) Prof Med Jour 17(1) 111-116 Jan, Feb, Mar 2010.

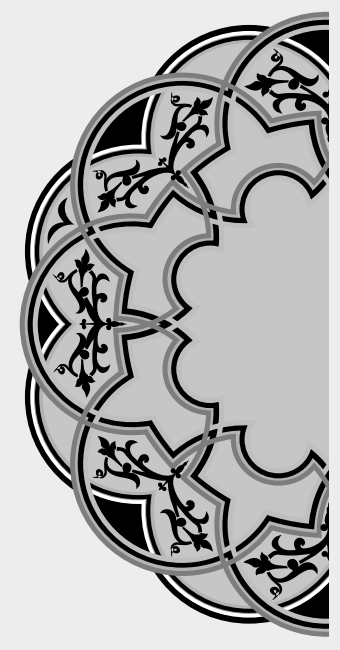

\section{"We tend to judge others by their behavior, and ourselves by our intentions.}

Unknown

\section{AUTHORSHIP AND CONTRIBUTION DECLARATION}

\begin{tabular}{|c|c|c|c|}
\hline Sr. \# & Author-s Full Name & Contribution to the paper & Author $=$ s Signature \\
\hline 1 & Dr. Santosh Kumar & $\begin{array}{l}\text { Main Author, Contribute } \\
\text { idea, syn statics, analysis } \\
\text { \& research }\end{array}$ & \\
\hline 2 & Dr. Gaffar Memon & $\begin{array}{l}\text { Collection of sample and } \\
\text { reference }\end{array}$ & \\
\hline 3 & Dr. Bagwan Das & $\begin{array}{l}\text { Contributes in sample } \\
\text { collection \& biostatics }\end{array}$ & \\
\hline 4 & Dr. Pushpa Mohan & Research - Statics & \\
\hline
\end{tabular}

